\title{
Cyscicerci in the longus colli in disseminated cysticercosis: an unusual location for a common endemic disease
}

\author{
Krishnarpan Chatterjee, Gopal Chandra Ghosh, Bhimaray Katageri, Brijesh Sharma
}

Department of Internal Medicine, PGIMER \& Dr RML Hospital, New Delhi, India

\section{Correspondence to} Dr Gopal Chandra Ghosh gcghosh86@gmail.com
To cite: Chatterjee $\mathrm{K}$, Ghosh GC, Katageri B, et al. BMJ Case Rep Published online: [please include Day Month Year] doi:10.1136/ bcr-2013-010405

\section{DESCRIPTION}

A 22-year-old woman residing in New Delhi presented to the department of medicine with a history of insidious onset, progressive headache for the last 6 months. The headache was bilateral, dull aching in nature radiating to the neck and jaws. It was associated with fatigue, low mood, irritability, loss of appetite and crying spells. After 3 months of persistent symptoms she had consulted a physician who diagnosed her to have chronic tension type headache with mild depressive episode and started on amitryptiline $25 \mathrm{mg}$ once daily for prophylaxis. The general examination was unremarkable. There were no subcutaneous swellings. Central nervous system examination was normal. Rest of the systemic examination was normal. A non-contrast CT of the head showed multiple hypodense lesions in brain parenchyma. A contrast enhanced MRI was performed, which showed ring-enhancing lesions and multiple cystic lesions with eccentric nodules (scolex) bilaterally in the brain (figure 1). Similar lesions were seen in the scalp, paravertebral muscles including longus colli, pharyngeal muscles, masseter and pterygoids and tongue (figure 2). X-ray of the thigh showed multiple cigar-shaped calcifications. Creatine kinase was not raised. Based on the imaging findings a definite diagnosis of neurocysticercosis with extra-cranial dissemination was made. She was started on oral steroids and imaging follow-up was planned. Amitryptiline was stopped. At 2 months follow-up her headache had decreased and she did not report any myalgia. There was

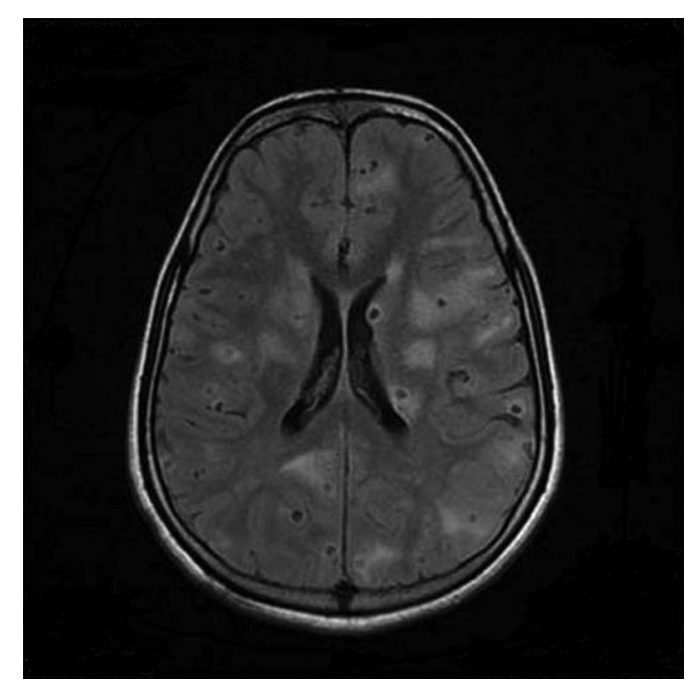

Figure 1 MRI brain showing multiple hypodense lesions with perilesional oedema involving bilateral brain parenchyma, few of them showing eccentric scolices.

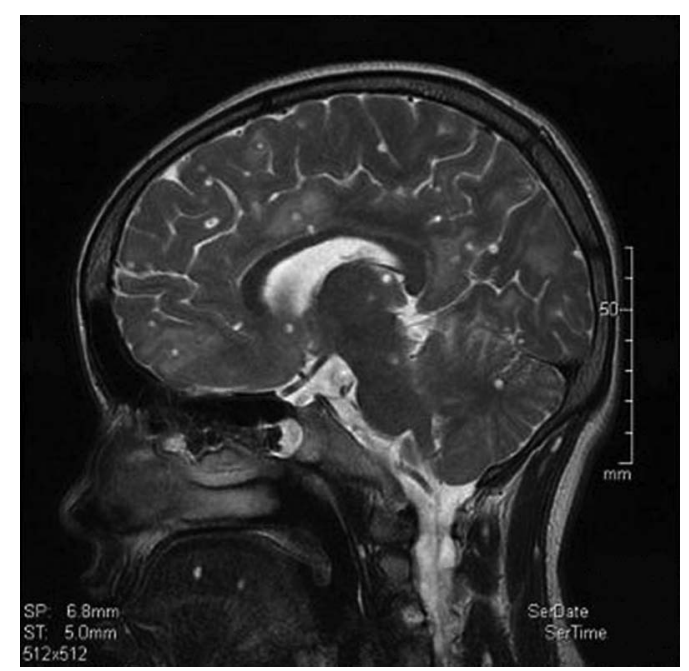

Figure 2 MRI showing cysticerci in intracranial as well as extracranial locations including paravertebral neck muscles (longus colli), tongue muscles and pharyngeal wall muscles.

significant improvement in her mood as documented by psychiatry consultation. Disseminated cysticercosis is an unusual presentation of a common helminthic infection caused by the spread of embryos of Taenia solium from the intestine via the hepatoportal system to the tissues and organs of the body. The clinical pleomorphism of cysticercosis mainly related to individual differences in the number and location of the lesions and also to variations in the severity of the disease, initially led to the misdiagnosis of chronic tension type headache with mild depression. Extracranial cysticerci are seen in skeletal muscles. Cysticerci are uncommon in the head and neck region but cases of cysticerci of tongue, masseter, mylohyoid, lower lip, soft palate and sternocleidomastoid have been reported previously. ${ }^{1}{ }^{2}$ Such widespread presence with involvement of atypical muscles like pterygoids,

\section{Learning points}

- In endemic areas headache and musculoskeletal pains may be due to cysticerci.

- Cysticercosis may involve atypical sites like masseter, pterygoid, paravertebral muscles, posterior pharyngeal wall muscles.

- Non-invasive investigation modalities like MRI can be used for early diagnosis even in the absence of palpable swellings. 
paravertebral neck muscles and pharyngeal wall muscles has not been documented in previous literature.

Competing interests None.

Patient consent Obtained.

Provenance and peer review Not commissioned; externally peer reviewed.

\section{REFERENCES}

1 Sharma R, Gautam P, Kumar S, et al. Isolated cysticercosis cellulosae of sternocleidomastoid muscle: a case report with review of literature. Indian J Otolaryngol Head Neck Surg 2011;63:127-30.

2 Virk RS, Panda N, Ghosh S. Mylohyoid cysticercosis: a rare submandibular mass. Ear Nose Throat J 2009;88:1218-20.

Copyright 2013 BMJ Publishing Group. All rights reserved. For permission to reuse any of this content visit http://group.bmj.com/group/rights-licensing/permissions.

BMJ Case Report Fellows may re-use this article for personal use and teaching without any further permission.

Become a Fellow of BMJ Case Reports today and you can:

- Submit as many cases as you like

- Enjoy fast sympathetic peer review and rapid publication of accepted articles

- Access all the published articles

- Re-use any of the published material for personal use and teaching without further permission

For information on Institutional Fellowships contact consortiasales@bmjgroup.com

Visit casereports.bmj.com for more articles like this and to become a Fellow 